\title{
БУЛІНГ В ДЕРЖАВНІЙ СЛУЖБІ: СОЦІАЛЬНО-ПСИХОЛОГІЧНИЙ АСПЕКТ
}

Алюшина Н. О., голова, Національне агентство України з питань державної служби, канд. психол., наук, доцент, м. Київ, Україна.

У науковій статті подано результати соціальнопсихологічного дослідження щзодо проявів булінгу на державній службі в Україні. Виявлено, із застосуванням методу сочіологічного опитування, випадки застосування булінгу, досліджено особливості прояву такого явища та иляхи захисту прав державних службовиів у зв'язку з булінгом. В опитуванні взяло участь 1042 держаних службовців. Опитування проведено методом анкетування. При обробиі результатів опитування використано метод корелячійного аналізу (коефіцієнт корелячії Пірсона). Визначення кореляиійних зв'язків здійснено за допомогою використання програмного забезпечення IBM SPSS Statistic 21.

Ключові слова: державна служба, державні службовиі, управління персоналом, сочіально-психологічний механізм управління персоналом, булінг, изькування.

Постановка проблеми у загальному вигляді. Одна 3 проблем, яка стала актуальною для публічної сфери України - поширене цькування (булінг) серед публічних службовців. Ситуацій, коли одна публічна особа чи група осіб ображають, цькують іншу публічну особу, щороку стає більше. 3 прийняттям 18 грудня 2018 року Верховною Радою України Закону про внесення змін до деяких законодавчих актів України щодо протидії булінгу тягне за собою ряд змін у вирішенні зазначеної проблеми. Однак, цим законом в основному регулюються питання булінгу лише у сфері освіти. 
Зауважимо, що під булінгом як правило розуміються діяння учасників освітнього процесу, які полягають у психологічному, фізичному, економічному, сексуальному насильстві, у тому числі із застосуванням засобів електронних комунікацій, що вчиняються стосовно особи, внаслідок чого могла бути чи була заподіяна шкода психічному або фізичному здоров'ю потерпілого.

Аналіз останніх досліджень і публікацій. Як показують численні зарубіжні дослідження, на сьогоднішній день проблема актуальна у всьому світі. Зокрема досліджено такі аспекти як: методи роботи 3 ситуаціями цькування, де загострено особливу увагу на послідовність чотирьох етапів і правильності сприйняття мети, а також завдань представленого методу (В. Богомолов S.Young, А. Сью Янг та ін.) [1; 5]; динаміка розповсюдження та масштабність цієї соціальної проблеми (О. Гусейнова, С. Сніколопов та ін.) [3 та ін.]; проблема кибербулингу, де робиться висновок, що нинішнє молоде покоління соціалізується більшою мірою саме в Інтернеті, в соціальних мережах і в інформаційному просторі в цілому (А. Бочавер, К. Хломов та ін.) [2]; різні типи цькування, наслідки і впливи на різні групи людей, також водиться новий термин - хейзинг (I. Кон, О. Чебикін та ін.) та методика уникнення булінгу в організаційних системах (I. Бринза, Е. Куценко, Л. Петрановська та ін.) [4] та інші.

У зазначеному контексті варто відзначити, що у сфері публічного управління та адміністрування дана проблема не була предметом окремого дослідження. В рамках підготовки Концепції культури на державній службі у 2019 році Генеральним департаментом з питань управління персоналом на державній службі НАДС ініційовано питання щодо випадків булінгу на державній службі. Експертами зазначалося, що проявами булінгу на роботі є: навмисне обмеження доступу до необхідної інформації, постійна необгрунтована критика та незадовільна оцінка роботи керівництвом, надмірна прискіпливість, соціальна ізоляція в колективі, жарти та коментарі сексуального характеру, безпідставна зміна чи погіршення умов роботи та відпочинку, вербальна агресія, приписування успіхів іншим працівникам, відсутність визнання досягнень та успіхів, пошкодження майна тощо. 


\section{Формулювання цілей статті (постановка завдання).} Виявити, iз застосуванням методу соціологічного опитування, випадки застосування булінгу, дослідити особливості прояву такого явища та шляхи захисту прав державних службовців у зв’язку з булінгом.

Виклад основного матеріалу дослідження. Опитування проведено методом анкетування. При обробці результатів опитування використано метод кореляційного аналізу (коефіцієнт кореляції Пірсона). Визначення кореляційних зв’язків здійснено за допомогою використання програмного забезпечення IBM SPSS Statistic 21. В опитуванні взяло участь 1042 держаних службовців. 3 них представники державних органів, рівень юрисдикції яких: $41,5 \%$ - територія одного або кількох районів, міст обласного значення; 32,9 \% - територія однієї або кількох областей, міста Києва або Севастополя; 25,5 \% - вся територія України.

Державні службовці, які взяли участь в опитуванні займають такі посади державної служби: 1,4 \% - категорії «А»; 35,7 \% - категорії «Б»; 62,9 \% - категорії «В». За гендерною ознакою в опитуванні взяло участь $77,1 \%$ жінок та 22,9 \% чоловіків. За стажем роботи на державній службі розподіл респондентів зображено на рис.1.

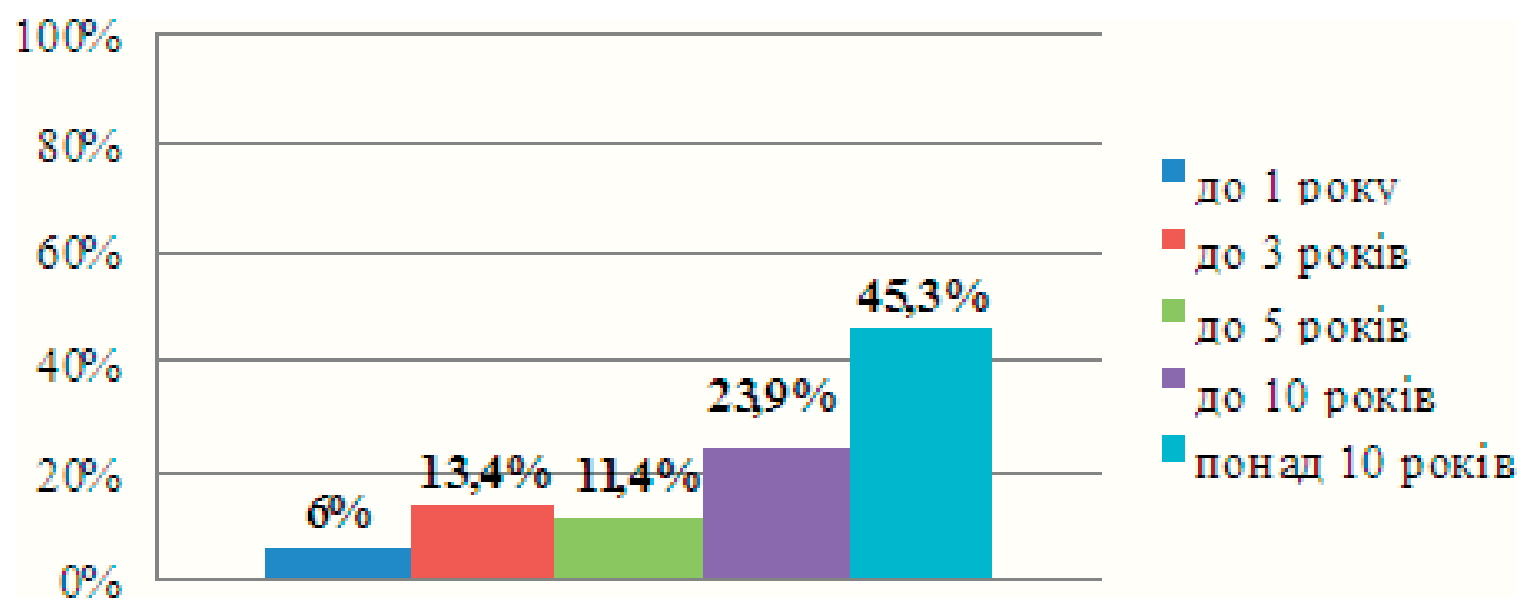

Puc. 1. Розподіл респондентів за стажем роботи.

За результатами аналізу отриманих даних, 66,1 \% державних службовців стикалися по відношенню до себе з випадками булінгу на державній службі та 33,9 \% - не стикалися (рис.2). 


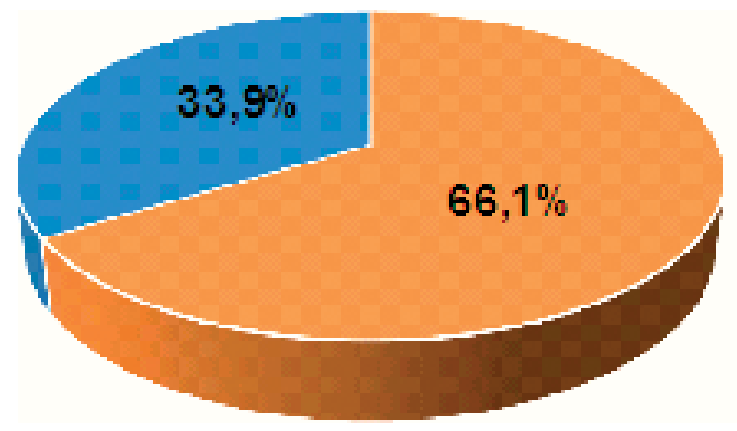

- Стикали ся 3 вип адками булін нгу

- Не стикалися 3 вип адками булінгу

Puc.2. Наявність випадків булінгу на державній службі.

Встановлено негативний кореляційний зв'язок $(\mathrm{p} \leq 0,01)$ між явищем застосування булінгу та категорією посади державної служби. Це свідчить про те, що чим нижча категорія посади державної служби, тим вищий ризик застосування булінгу. Стать, стаж державної служби та рівень юрисдикції державного органу не впливають на наявність чи відсутність факту прояву булінгу щодо державних службовців.

Кореляційних зв'язків між систематичністю застосування булінгу та категорією посади державної служби, статтю, стажем державної служби, рівнем юрисдикції державного органу не встановлено. Це свідчить про те, що зазначені фактори не впливають на систематичність застосування булінгу щодо державних службовців.

Серед проявів булінгу, з якими стикалися державні службовці по відношенню до себе на державній службі респонденти зазначили (рис.3): 55,2 \% - постійна необгрунтована критика та незадовільна оцінка роботи керівництвом, надмірна прискіпливість та перевірка поточної роботи; 50,9 \% - вербальна агресія (умисні висловлювання інших осіб, спрямовані викликати негативні переживання, образи, погрози); 49,3 \% - поширення чуток та недостовірної інформації серед трудового колективу, що мали негативний вплив на репутацію; 
«Public Administration and Regional Development» https://pard.mk.ua/index.php/journal

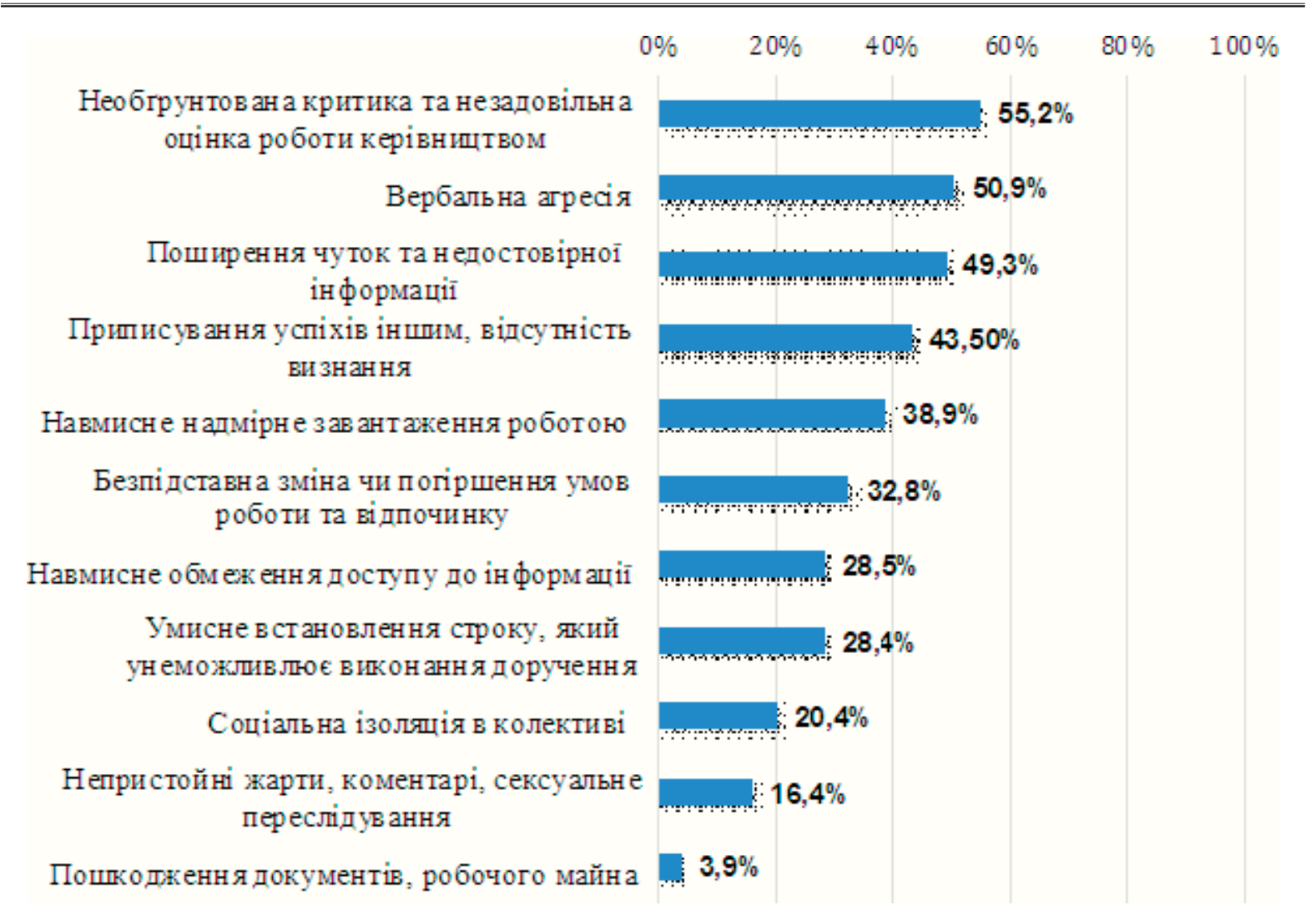

Puc.3. Прояви булінгу, з якими стикалися державні службовці.

43,5 \% - приписування успіхів іншим працівникам, відсутність визнання досягнень і успіхів; 38,9 \% - навмисне надмірне завантаження роботою у порівнянні з іншими працівниками та/або доручення завдань, які не відповідають рівню компетенції; 32,8 \% безпідставна зміна чи погіршення умов роботи та відпочинку (перенесення відпустки на не зручний час, постійне включення до графіку чергування, періодичне перенесення робочого місця, погіршення умов матеріально-технічного забезпечення); 28,5 \% навмисне обмеження доступу до необхідної інформації, право доступу до якої є у державного службовця; 28,4 \% - умисне систематичне встановлення строку, який унеможливлює належне виконання доручення (завдання надходять 3 необгрунтовано коротким строком або після строку виконання чи у кінці останнього дня строку виконання); 20,4 \% - соціальна ізоляція в колективі (не запрошують на наради, загальні збори, корпоративні заходи, не спілкуються тощо); 16,4 \% - непристойні жарти, коментарі, 
сексуальне переслідування; 3,9 \% - пошкодження документів, робочого майна тощо.

Крім того, окремі респонденти зазначили про такі прояви булінгу, як цькування перед усім колективом, фізичне переслідування в робочий та позаробочий час (в тому числі по телефону), погрози звільнити за те що перебуваєш на лікарняному з дитиною, заборона пити каву та чай, заборона спілкування з колегами.

За результатами кореляційного аналізу виявлено причиннонаслідкові зв'язки між деякими проявами булінгу та окремими статистичними характеристиками. Встановлено негативні кореляційні зв'язки між таким проявом булінгу, як навмисне обмеження доступу до необхідної інформації, право доступу до якої є у державного службовця, та статтю респондентів $\left(\mathrm{p}_{\leq} 0,01\right)$, категорією посади державної служби $\left(\mathrm{p}_{\leq} 0,05\right)$. Це свідчить про те, що зазначений прояв булінгу частіше застосовується щодо чоловіків та вищих категорій посад державної служби. Встановлено позитивний кореляційний зв'язок між рівнем юрисдикції державного органу та таким проявом булінгу, як соціальна ізоляція $\left(\mathrm{p}_{\leq} 0,01\right)$. Це вказує на те, що зазначений прояв булінгу є більш характерним для державних органів рівень юрисдикції яких - вся територія України. Також виявлено, що чим більший стаж державної служби, тим вищий ризик застосування такого прояву булінгу, як навмисне надмірне завантаження роботою у порівнянні з іншими працівниками та/або доручення завдань, які не відповідають рівню компетенції $\left(\mathrm{p}_{\leq} 0,05\right)$.

Булінг по відношенню до державних службовців застосовували (рис.4): $60 \%$ - безпосередній керівник; 44,4 \% - керівник вищого рівня; 23,4 \% - колеги із структурного підрозділу; 17,8 \% - колеги 3 інших структурних підрозділів; 15,7 \% - керівники інших структурних підрозділів; 5,1 \% - колеги з інших державних органів, 3 якими здійснюється співпраця.

За результатами кореляційного аналізу встановлено позитивні та негативні кореляційні зв'язки $(\mathrm{p} \leq 0,01)$ між проявами булінгу та особами, які його застосовують, що свідчать про схильність окремих категорій осіб до певних проявів булінгу у разі його застосування (табл. 1). 


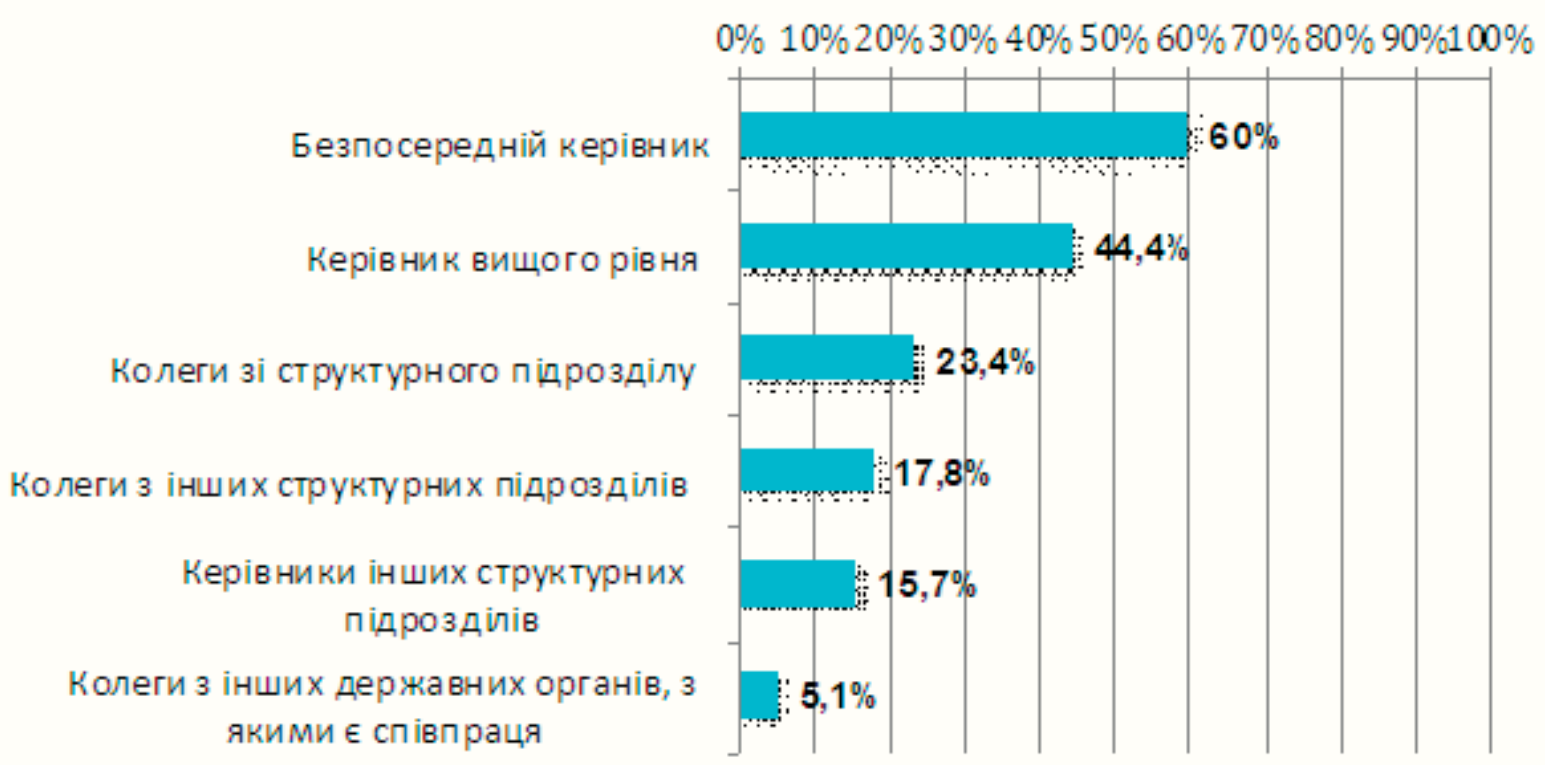

Puc.4. Категорії осіб, які застосовували булінг по відношенню до державних службовців.

\section{Категорія осіб що має схильність до певних проявів булінгу}

\begin{tabular}{|l|l|}
\hline Категорія осіб & Схильність до проявів булінгу у разі застосування \\
\hline Колеги зі & 1) вербальна агресія; \\
птруктурного & 2) поширення чуток та недостовірної інформації серед \\
& трудового колективу, що мали негативний вплив на ре- \\
& путацію; \\
3) соціальна ізоляція в колективі; & 4) приписування успіхів іншим працівникам, відсут- \\
& $\begin{array}{l}\text { ність визнання досягень і успіхів; } \\
\text { 5) непристойні жарти, коментарі, сексуальне пере- } \\
\text { слідування. }\end{array}$ \\
\hline $\begin{array}{l}\text { Колеги з інших } \\
\text { структурних } \\
\text { підрозділів }\end{array}$ & $\begin{array}{l}\text { м) навмисне обмеження доступу до необхідної інфор- } \\
\text { 2) постійна необгорунтована критика та незадовільна } \\
\text { оцінка роботи, надмірна прискіпливість; } \\
\text { 3) поширення чуток та недостовірної інформації серед } \\
\text { трудового колективу, що мали негативний вплив на ре- } \\
\text { путацію. }\end{array}$ \\
\hline
\end{tabular}


Булінг в державній службі: соиіально-психологічний аспект

продовження таблииі 1

\begin{tabular}{|c|c|}
\hline Категорія осіб & Схильність до проявів булінгу у разі застосування \\
\hline $\begin{array}{l}\text { Безпосередній } \\
\text { керівник }\end{array}$ & $\begin{array}{l}\text { 1) постійна необгрунтована критика та незадовільна } \\
\text { оцінка роботи, надмірна прискіпливість та перевірка } \\
\text { поточної роботи; } \\
\text { 2) безпідставна зміна чи погіршення умов роботи та } \\
\text { відпочинку; } \\
\text { 3) поширення чуток та недостовірної інформації серед } \\
\text { трудового колективу, що мали негативний вплив на ре- } \\
\text { путацію; } \\
\text { 4) соціальна ізоляція в колективі; } \\
\text { 5) навмисне надмірне завантаження роботою у порів- } \\
\text { нянні з іншими працівниками та/або доручення зав- } \\
\text { дань, які не відповідають рівню компетенції; } \\
\text { 6) приписування успіхів іншим працівникам, відсут- } \\
\text { ність визнання досягнень і успіхів. }\end{array}$ \\
\hline $\begin{array}{l}\text { Керівник ви- } \\
\text { щого рівня }\end{array}$ & $\begin{array}{l}\text { 1) безпідставна зміна чи погіршення умов роботи та } \\
\text { відпочинку; } \\
\text { 2) умисне систематичне встановлення строку, який } \\
\text { унеможливлює належне виконання доручення. }\end{array}$ \\
\hline $\begin{array}{l}\text { Керівники ін- } \\
\text { ших структур- } \\
\text { них підрозділів }\end{array}$ & $\begin{array}{l}\text { 1) навмисне обмеження доступу до необхідної інфор- } \\
\text { мації, право доступу до якої є у державного службовця }\end{array}$ \\
\hline $\begin{array}{l}\text { Колеги з інших } \\
\text { державних ор- } \\
\text { ганів } 3 \text { якими } \\
\text { здійснюється } \\
\text { співпраця }\end{array}$ & $\begin{array}{l}\text { 1) навмисне обмеження доступу до необхідної інфор- } \\
\text { мації, право доступу до якої є у державного службовця; } \\
\text { 2) непристойні жарти, коментарі, сексуальне пере- } \\
\text { слідування. }\end{array}$ \\
\hline
\end{tabular}

Встановлено, що чим вищий рівень юрисдикції державного органу, тим більша імовірність прояву булінгу з боку керівників $(\mathrm{p} \leq 0,01)$ та колег 3 інших структурних підрозділів $(\mathrm{p} \leq 0,05)$. Це може бути пов'язано із більшою штатно-посадовою чисельністю та, відповідно, більшою кількістю комунікацій між структурними підрозділами державних органів, рівень юрисдикції яких - вся територія України. 
Негативні кореляційні зв'язки між статтю респондентів та категоріями осіб, що можуть застосовувати булінг свідчить про те, що до жінок булінг частіше застосовують керівники вищого рівня $(\mathrm{p} \leq 0,01)$ та колеги з інших структурних підрозділів $\left(\mathrm{p}_{\leq} 0,05\right)$.

Виявлено, що чим більший стаж державної служби, тим більший ризик застосування булінгу 3 боку безпосереднього керівника $\left(\mathrm{p}_{\leq} 0,01\right)$. Також, безпосередній керівник частіше застосовує булінг до жінок, ніж до чоловіків.

Виявлено, що колеги з інших структурних підрозділів, керівник вищого рівня, керівники 3 інших структурних підрозділів та колеги з інших державних органів, частіше застосовують булінг до державних службовців, які працюють на державній службі менше одного року, ніж до інших державних службовців.

Це свідчить про те, що в державних органах між структурними підрозділами та державними органами, які є суб'єктами зовнішньої комунікації, існують домінантно-статусні стосунки, засновані на більш суб'єктивному, зверхньому та прискіпливому ставленні до державного службовця в залежності від його стажу роботи на державній службі. Такий тип стосунків не стосується взаємодії 3 колегами у структурному підрозділі та безпосереднім керівником.

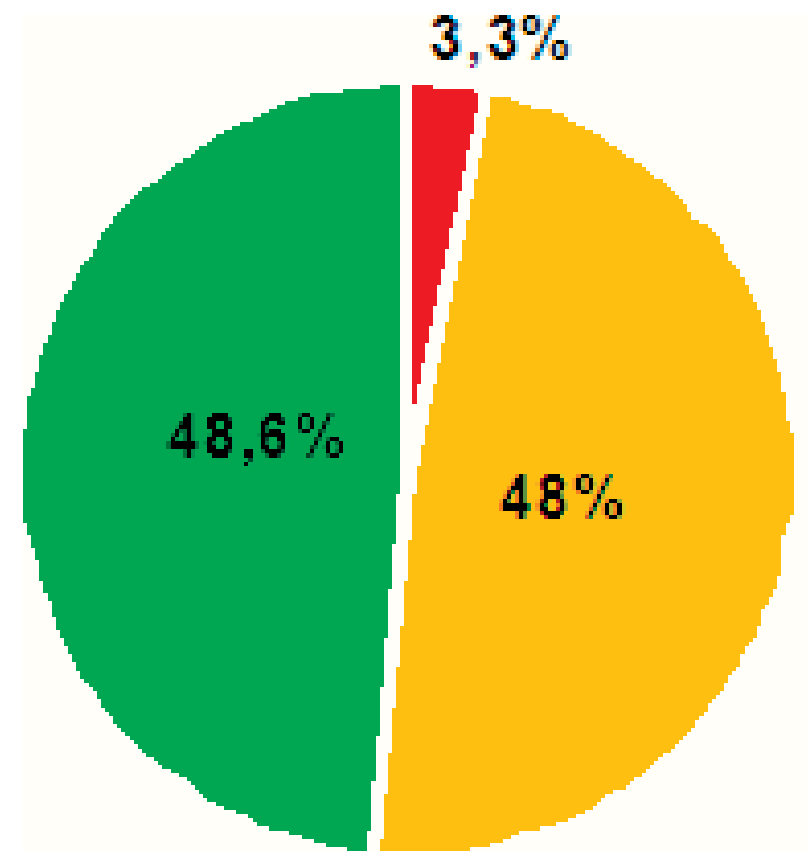

\section{- Один раз \\ Декілька разів \\ - Система тично}

Puc.5. Частота застосування боулінгу. 
За частотою по відношенню до державних службовців булінг застосовувався (рис.5): 48,6 \% - систематично; 48 \% - декілька разів; 3,3\% - один раз.

Респонденти зверталися за захистом своїх прав у зв'язку 3 булінгом до наступних фізичних та юридичних осіб (рис.6): 58,5 \% нікуди не звертались; 18,8 \% - безпосереднього керівника; 18,3 \% керівника вищого рівня; 15,1 \% - колег; 3,8 \% - служби управління персоналом; 2,8 \% - первинної профспілкової організації; 2 \% НАДС; 1,7 \% - суду; 1 \% - інших правозахисних організацій; 0,6 \% - профспілки працівників державних установ України.

Також респонденти зазначили, що звертались до поліції та Уповноваженого Верховної Ради з прав людини.

$0 \% \quad 10 \%$ 20\% 30\% 40\% 50\% 60\% 70\% 80\% 90\% $100 \%$

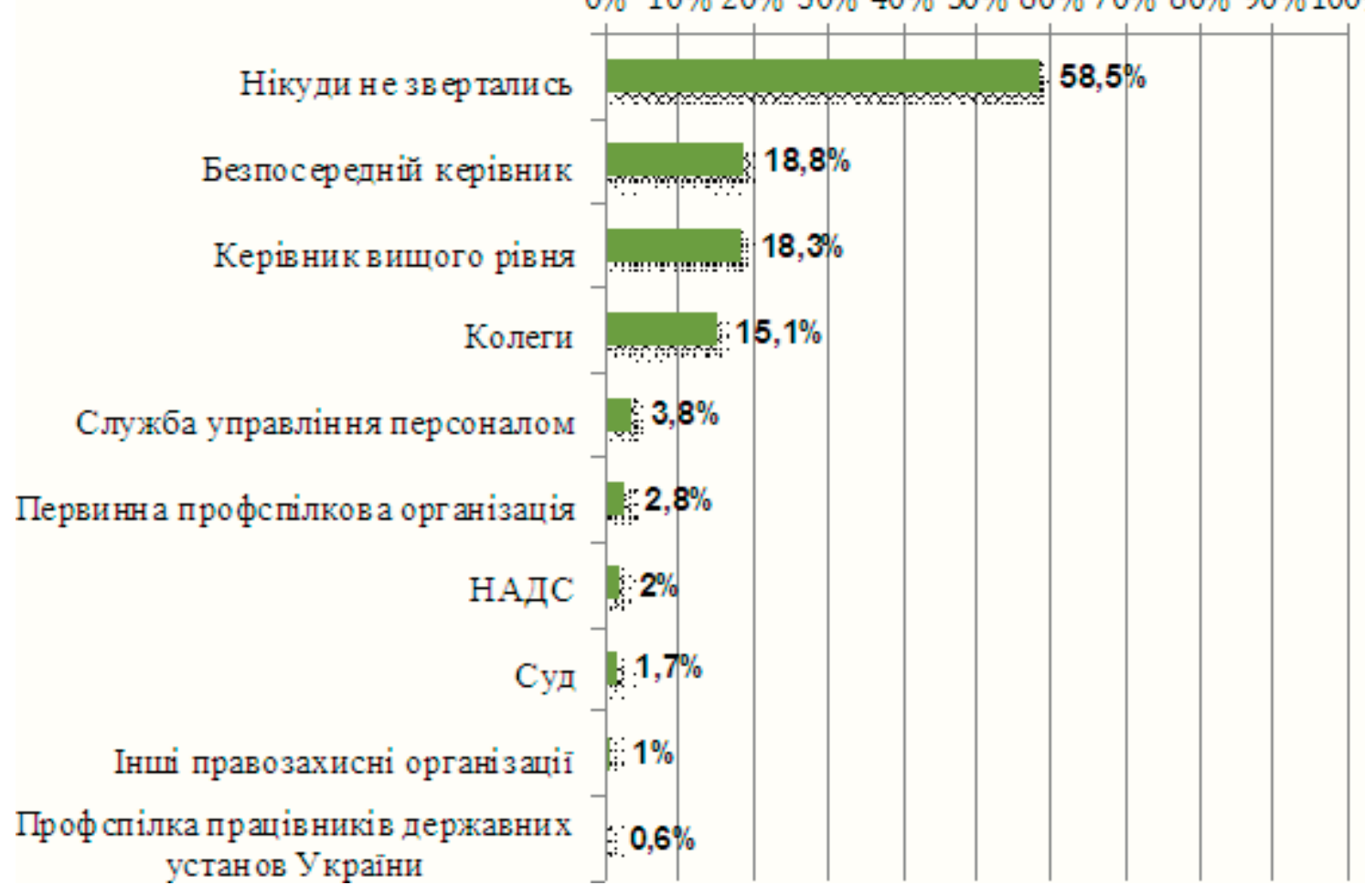

Puc.6. Фізичні та юридичні особи до яких звертались державні службовці за захистом свої прав під час застосування боулінгу.

Якщо 41,5 \% державних службовців визначити як $100 \%$ респондентів, які звернулися за захистом своїх прав у зв'язку з булінгом, то допомогу у вирішенні питань щодо булінгу отримали 15,4 \% державних службовців та 84,6 \% - не отримали. 
Якщо розглядати сукупність звернень до окремої фізичної чи юридичної особи, як 100 \%, то прослідковується такий відсоток, вирішених позитивно питань щодо булінгу, в результаті звернення державних службовців за захистом своїх прав до зазначених осіб (рис.7): 75 \% - профспілки працівників державних установ України; 35,5 \% - служби управління персоналом; 35,3 \% - Первинна профспілкова організації; 34,7 \% - колеги; 29,7 \% - керівник вищого рівня; 28,7 \% - безпосередній керівник; 16,7 \% - суд; 14,3 \% - НАДС; 11,1 \% - інші правозахисні організації.

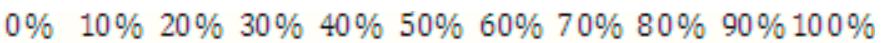

НАДС

\begin{tabular}{|l|l|l|}
\hline $14,3 \%$ & $86 \%$ \\
\hline & & \\
\hline $28,7 \%$ & $71 \%$ \\
\hline
\end{tabular}

Безпосередній керівник

Керівник вишого рівня

Служба управління персоналом

\begin{tabular}{|c|c|}
\hline $29,7 \%$ & $70 \%$ \\
\hline $35,5 \%$ & $65 \%$ \\
\hline $34,7 \%$ & $65 \%$ \\
\hline $16,7 \%$ & $83 \%$ \\
\hline
\end{tabular}

Первинн а профспілкова організація

Профспілка працівникі в державних установ У мраїни

Інші прав озахисні організаціі

\begin{tabular}{|c|c|c|}
\hline $35,3 \%$ & \multicolumn{2}{|c|}{$65 \%$} \\
\hline & & \\
\hline & $75 \%$ & $25 \%$ \\
\hline & & \\
\hline $11,1 \%$ & $89 \%$ & \\
\hline
\end{tabular}

Відсоток звернень шодо яких отримано допомогу
Відсоток звернень шодо яких не отримано допомогу

Puc. 7. Відсоток звернень завдяки яким отримано допомогу від фізичних та юридичних осіб у вирішенні питання щодо застосування боулінгу.

За результатами кореляційного аналізу встановлено позитивні кореляційні зв'язки між фізичними та юридичними особами, до 
Булінг в державній службі: сочіально-психологічний аспект

яких звертаюся державні службовці за захистом власних прав та деякими проявами булінгу. Це свідчить про те, що залежно від проявів (видів) булінгу, респонденти обирають звернення до різних фізичних та юридичних осіб (таблиця 2).

Табличяя 2.

Фізичні та юридичні особи до яких звертаюся державні службовці за захистом власних прав та проявами боулінгу

\begin{tabular}{|c|c|}
\hline $\begin{array}{c}\text { Фізичні та } \\
\text { юридичні } \\
\text { особи }\end{array}$ & $\begin{array}{c}\text { Прояв булінгу щодо якого звертаються державні } \\
\text { службовці у разі його застосування }\end{array}$ \\
\hline НАДС & $\begin{array}{l}\text { 1) соціальна ізоляція в колективі }(\mathrm{p} \leq 0,01) \text {; } \\
\text { 2) навмисне обмеження доступу до необхідної } \\
\text { інформації, право доступу до якої є у державного } \\
\text { службовця }(\mathrm{p} \leq 0,05) \text {. }\end{array}$ \\
\hline $\begin{array}{c}\text { Безпосе- } \\
\text { редній } \\
\text { керівник }\end{array}$ & $\begin{array}{l}\text { 1) навмисне обмеження доступу до необхідної } \\
\text { інформації, право доступу до якої } є \text { у державного } \\
\text { службовця }(\mathrm{p} \leq 0,01) \text {; } \\
\text { 2) постійна необгрунтована критика та } \\
\text { незадовільна оцінка роботи, надмірна прискіпливість та } \\
\text { перевірка поточної роботи }(\mathrm{p} \leq 0,05) \text {; } \\
\text { 3) поширення чуток та недостовірної інформації } \\
\text { серед трудового колективу, що мали негативний вплив на } \\
\text { Вашу репутацію }(\mathrm{p} \leq 0,05) \text {. }\end{array}$ \\
\hline $\begin{array}{c}\text { Керівник } \\
\text { вищого } \\
\text { рівня }\end{array}$ & 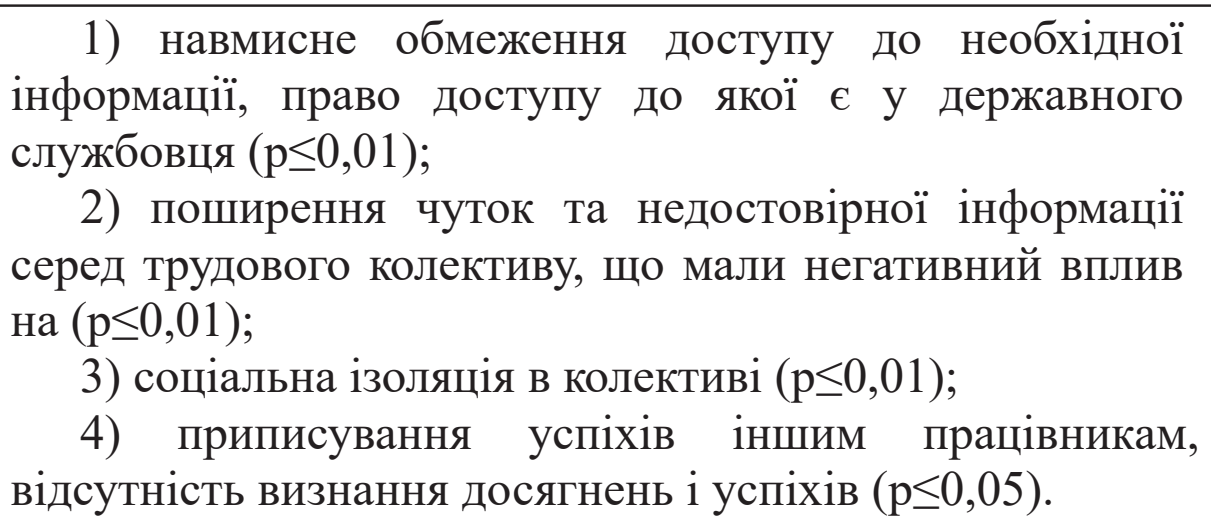 \\
\hline $\begin{array}{c}\text { Служба } \\
\text { управління } \\
\text { персоналом }\end{array}$ & $\begin{array}{l}\text { 1) соціальна ізоляція в колективі }(\mathrm{p} \leq 0,01) \text {; } \\
\text { 2) поширення чуток та недостовірної інформації } \\
\text { серед трудового колективу, що мали негативний вплив на } \\
\text { репутацію }(\mathrm{p} \leq 0,05) \text {. }\end{array}$ \\
\hline
\end{tabular}


продовження таблииі 2

\begin{tabular}{|c|c|}
\hline Колеги & 1) вербальна агресія $(\mathrm{p} \leq 0,05)$. \\
\hline \multirow[t]{2}{*}{ Суд } & 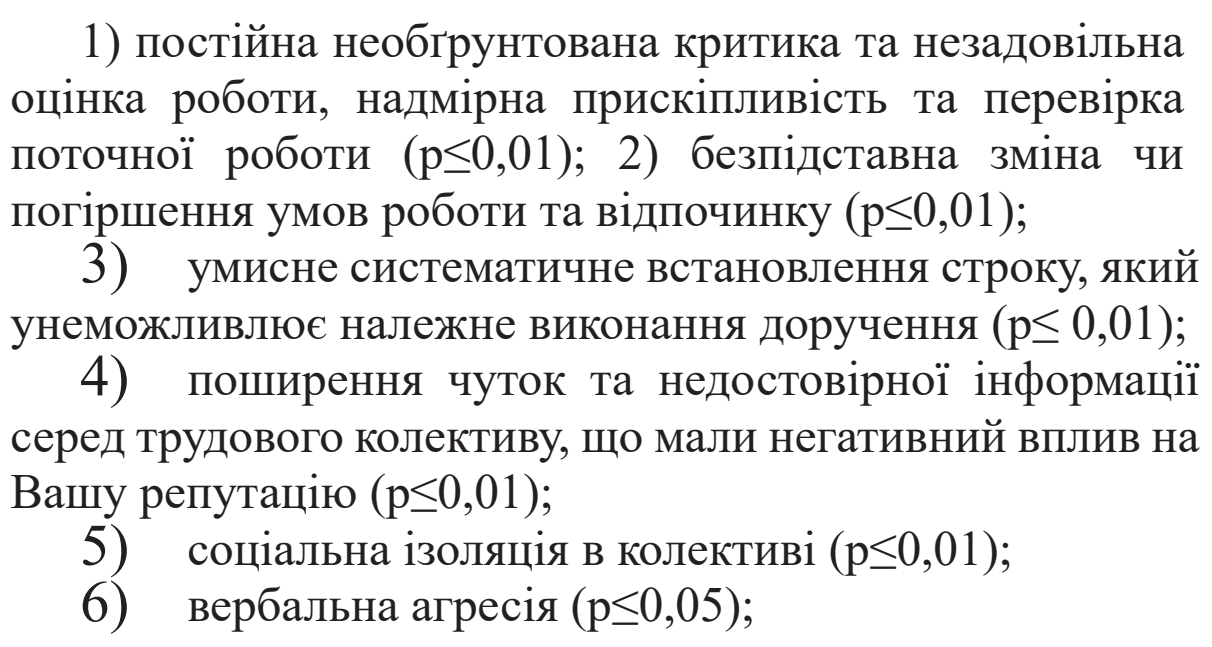 \\
\hline & $\begin{array}{l}\text { 7) навмисне обмеження доступу до необхідної } \\
\text { інформації, право доступу до якої } є \text { у державного } \\
\text { службовця }(\mathrm{p} \leq 0,05) \text {. }\end{array}$ \\
\hline $\begin{array}{c}\text { Первинна } \\
\text { профспілкова } \\
\text { організація }\end{array}$ & $\begin{array}{l}\text { 1) навмисне обмеження доступу до необхідної } \\
\text { інформації, право доступу до якої } є \text { у державного } \\
\text { службовця }(\mathrm{p} \leq 0,05) \text {; } \\
\text { 2) поширення чуток та недостовірної інформації } \\
\text { серед трудового колективу, що мали негативний вплив на } \\
\text { репутацію (p } \leq 0,05) \text {. }\end{array}$ \\
\hline $\begin{array}{c}\text { Профспілка } \\
\text { працівників } \\
\text { державних } \\
\text { установ } \\
\text { України }\end{array}$ & $\begin{array}{l}\text { 1) навмисне обмеження доступу до необхідної } \\
\text { інформації, право доступу до якої є у державного } \\
\text { службовця }(\mathrm{p} \leq 0,05) \text {. }\end{array}$ \\
\hline $\begin{array}{l}\text { Інші } \\
\text { правозахисні } \\
\text { організації }\end{array}$ & $\begin{array}{l}\text { 1) постійна необгрунтована критика танезадовільна } \\
\text { оцінка роботи керівництвом, надмірна прискіпливість та } \\
\text { перевірка поточної роботи }(\mathrm{p} \leq 0,01) \text {; } \\
\text { 2) соціальна ізоляція в колективі }(\mathrm{p} \leq 0,01) \text {; } \\
3) \text { навмисне обмеження доступу до необхідної } \\
\text { інформації, право доступу до якої є у державного } \\
\text { службовця (p } \leq 0,05) \text {; } \\
\text { 4) пошкодження документів, робочого майна тощо } \\
(\mathrm{p} \leq 0,05) \text {. }\end{array}$ \\
\hline
\end{tabular}


Встановлено, що чим вищий рівень юрисдикції державного органу, тим частіше державні службовці звертаються до таких фізичних та юридичних осіб за захистом своїх прав у разі застосування булінгу: суду $(\mathrm{p} \leq 0,01)$, Первинної профспілкової організації $(\mathrm{p} \leq 0,05)$.

Встановлено причинно наслідкові зв'язки та закономірності між зверненнями державних службовців за захистом прав до суду щодо таких проявів булінгу як безпідставна зміна чи погіршення умов роботи та відпочинку ( $\leq \leq 0,01)$, умисне систематичне встановлення строку, який унеможливлює належне виконання доручення $(\mathrm{p} \leq 0,05)$ та отриманням / неотриманням допомоги щодо свого звернення. Це свідчить про те, що при зверненні до суду стосовно таких питань частіше допомога не отримується.

Проте якщо державний службовець звертається до суду чи керівника вищого рівня стосовно такого прояву булінгу, як поширення чуток та недостовірної інформації серед трудового колективу, що мали негативний вплив на його репутацію, допомога отримується $(\mathrm{p} \leq 0,05)$. Можливо, це пов'язано із наявністю відповідного законодавства, що дозволяє захистити права державного службовця у зазначеній сфері.

Серед респондентів 87,1\% на цей час є державними службовцями та $12,9 \%$ - не є державними службовцями.

Шляхом кореляційного аналізу встановлено негативний кореляційний зв'язок $(\mathrm{p} \leq 0,01)$ між застосуванням булінгу та продовженням / припиненням роботи на державній службі. Тобто чим рідше застосовується булінг, тим вищий шанс, що працівник продовжить працювати на посаді державної служби. Таким чином, статистично доведено, що булінг є одним із факторів плинності кадрів на державній службі.

Серед тих, хто на цей час не є державними службовцями, булінг став причиною звільнення у 64,9 \% випадках.

Зокрема, встановлено позитивні кореляційні зв'язки між такими проявами булінгу, як вербальна агресія $(\mathrm{p} \leq 0,01)$, пошкодження документів, робочого майна та наявністю / втратою статусу державного службовця $(\mathrm{p} \leq 0,05)$. Це свідчить про те, що такі 
прояви булінгу найчастіше провокують державних службовців до звільнення.

Також відповідно до встановленого кореляційного зв'язку ризик звільнення державного службовця після булінгу підвищується, якщо булінг застосовують колеги зі структурного підрозділу та безпосередній керівник $(\mathrm{p} \leq 0,05)$.

Представимо результати аналізу опитування державних службовців, які займають посади державної служби категорії «А». Так, серед репондентів, які займають посади державної служби категорії «А», 50 \% державних службовців стикалися з випадками булінгу щодо себе. 3 них 28,6 \% - представники чоловічої статі та 71,4 \% - жіночої. 57,2 \% державних службовців, які стикалися 3 випадками булінгу щодо себе, працюють в державних органах, рівень юрисдикції яких територія одного або кількох районів, міст обласного значення та 42,8 \% - вся територія України.

Серед респондентів категорії «А», по відношенню до яких застосовувався булінг, зазначено такі прояви: 71,4 \% - вербальна агресія; 57,1 \% - постійна необгрунтована критика та незадовільна оцінка роботи керівництвом, надмірна прискіпливість та перевірка поточної роботи; 57,1 \% - поширення чуток та недостовірної інформації серед трудового колективу, що мали негативний вплив на репутацію; 57,1 \% - непристойні жарти, коментарі, сексуальне переслідування; 42,9 \% - приписування успіхів іншим працівникам, відсутність визнання досягнень і успіхів; 28,6 \% навмисне надмірне завантаження роботою у порівнянні з іншими працівниками та/або доручення завдань, які не відповідають рівню компетенції; 28,6 \% - безпідставна зміна чи погіршення умов роботи та відпочинку; 28,6\% - умисне систематичне встановлення строку, який унеможливлює належне виконання доручення; $28,6 \%$ - соціальна ізоляція в колективі; 28,6 \% - пошкодження документів, робочого майна тощо; $14,3 \%$ - навмисне обмеження доступу до необхідної інформації, право доступу до якої $є$ у державного службовця.

Булінг по відношенню до державних службовців категорії «А» застосовували: 71,4 \% - безпосередній керівник; 42,9 \% - 
керівник вищого рівня; 28,6 \% - колеги (із структурного підрозділу, іншого структурного підрозділу, інших державних органів 3 якими здійснюється співпраця) та керівники інших структурних підрозділів/державних органів.

За частотою булінг застосовувався: 42,9 \% - систематично; $42,9 \%$ - декілька разів; 6,1 \% - один раз. У 71,4 \% випадків застосування булінгу колеги ставали на захист державного службовця.

За захистом свої прав державні службовці категорії «А» зверталися до таких фізичних та юридичних осіб: 57,1 \% - нікуди не звертались; 42,9 \% - до колег; 14,3 \% - до безпосереднього керівника, керівника вищого рівня, суду, первинної профспілкової організації. Допомогу у вирішенні питання щодо булінгу отримали 28,6 \% державних службовців. У 42,8 \% випадках булінг став причиною звільнення з посади державної служби.

Результати кореляційного аналізу відсутні, оскільки обсяг вибірки державних службовців категорії «А» недостатній для його застосування.

Щодо результатів опитування державних службовців, які займають посади державної служби категорії «Б» зазначимо таке:

Серед респондентів, які займають посади державної служби категорії «Б», 60,4 \% державних службовців стикалися з випадками булінгу щодо себе. 3 них 24,9 \% - представники чоловічої статі та 71,4 \% - жіночої. 42,2 \% - державних службовців, які стикалися 3 випадками булінгу працюють в державних органах, рівень юрисдикції яких територія одного або кількох районів, міст обласного значення, 34,4 \% - територія однієї або кількох областей, міста Києва або Севастополя та 23,5 \% - вся територія України.

Серед респондентів категорії «Б», по відношенню до яких застосовувався булінг, зазначено такі прояви: 58,5 \% постійна необгрунтована критика та незадовільна оцінка роботи керівництвом, надмірна прискіпливість та перевірка поточної роботи; 54 \% - поширення чуток та недостовірної інформації серед трудового колективу, що мали негативний вплив на репутацію; 49,1 \% - вербальна агресія; 47,8 \% - приписування успіхів іншим 
працівникам, відсутність визнання досягнень і успіхів; 36,2 \% безпідставна зміна чи погіршення умов роботи та відпочинку; 35,3 \% - навмисне обмеження доступу до необхідної інформації, право доступу до якої є у державного службовця; 34,4 \% - навмисне надмірне завантаження роботою у порівнянні зіншими працівниками та/або доручення завдань, які не відповідають рівню компетенції; $30,4 \%$-умисне систематичне встановлення строку, який унеможливлює належне виконання доручення; 23,7 \% - соціальна ізоляція в колективі; 14,3\% - непристойні жарти, коментарі, сексуальне переслідування; 5,4 \% - пошкодження документів, робочого майна тощо.

Також встановлено негативний кореляційний зв'язок між таким проявом булінгу, як безпідставна зміна чи погіршення умов роботи та відпочинку та стажем державної служби $(\mathrm{p} \leq 0,05)$. Тобто, у разі застосування булінгу зазначений його прояв буде частіше застосовуватися до державних службовців категорії «Б» 3 меншим стажем роботи на державній службі.

Булінг по відношенню до державних службовців категорії «Б» застосовували: 59,4 \% - безпосередній керівник; 49,6 \% - керівник вищого рівня; 18,8 \% - колеги зі структурного підрозділу; 17 \% керівники інших структурних підрозділів; 12,5 \% - колеги з інших структурних підрозділів; 5,8 \% - колеги з інших державних органів, 3 якими здійснюється співпраця.

За частотою булінг застосовувався: 47,3 \% - систематично; 48,7 \% - декілька разів; 4 \% - один раз. У 44,6 \% колеги ставали на захист від застосування булінгу. За захистом свої прав державні службовці категорії «Б» зверталися до таких фізичних та юридичних осіб: 55,4 \% - нікуди не звертались; 20,1 \% безпосереднього керівника; 19,2 \% - керівника вищого рівня; $10,7 \%$ - колег; 5,4 \% - служби управління персоналом; 3,6 \% НАДС; первинної профспілкової організації; 3,1 \% - суду; 2,2 \% інших правозахисних організацій; 1,3 \% - профспілки працівників державних установ України. Допомогу у вирішенні питання щодо булінгу отримали 16,1 \% державних службовців. У 65 \% випадках булінг став причиною звільнення з посади державної служби. 
Опитування державних службовців, які займають посади державної служби категорії «В», дали такі результати. Серед респондентів, які займають посади державної служби категорії «В», 69,9 \% державних службовців стикалися з випадками булінгу щодо себе. 3 них 21,6 \% - представники чоловічої статі та 78,3 \% жіночої. 41 \% - які стикалися 3 випадками булінгу працюють в державних органах, рівень юрисдикції яких - територія одного або кількох районів, міст обласного значення, 32,8 \% - територія однієї або кількох областей, міста Києва або Севастополя та 26,2 \% - вся територія України.

Серед респондентів категорії «В», по відношенню до яких застосовувався булінг, зазначено такі прояви: 55 \% - постійна необгрунтована критика та незадовільна оцінка роботи керівництвом, надмірна прискіпливість та перевірка поточної роботи; 51,5 \% вербальна агресія; 46,5 \% - поширення чуток та недостовірної інформації серед трудового колективу, що мали негативний вплив на репутацію; 40,6 \% - приписування успіхів іншим працівникам, відсутність визнання досягнень і успіхів; 40,4 \% - навмисне надмірне завантаження роботою у порівнянні з іншими працівниками та/або доручення завдань, які не відповідають рівню компетенції; 36 \% безпідставна зміна чи погіршення умов роботи та відпочинку; $27,4 \%$ - умисне систематичне встановлення строку, який унеможливлює належне виконання доручення; 26,1 \% - навмисне обмеження доступу до необхідної інформації, право доступу до якої $\epsilon$ у державного службовця; 18,9 \% - соціальна ізоляція в колективі; 14,9 \% - непристойні жарти, коментарі, сексуальне переслідування; 4,4 \% - пошкодження документів, робочого майна тощо.

Серед респондентів категорії «В» встановлено залежність деяких проявів булінгу на державній службі від рівня юрисдикції державного органу, статі та стажу. Зокрема, встановлено негативні та позитивні кореляційні зв'язки між рівнем юрисдикції державного органу та деякими проявами булінгу. Тобто, чим вищий рівень юрисдикції державного органу, тим більше існує схильність до таких проявів булінгу по відношенню до представників категорії «В», як: навмисне обмеження доступу до необхідної інформації, 
право доступу до якої є у державного службовця ( $\mathrm{p} \leq 0,01)$, соціальна ізоляція в колективі $(\mathrm{p} \leq 0,01)$, приписування успіхів іншим працівникам, відсутність визнання досягнень і успіхів $(\mathrm{p} \leq 0,05)$ та пошкодження документів, робочого майна тощо $\left(\mathrm{p}_{\leq} 0,01\right)$.

В державних органах 3 нижчим рівнем юрисдикції більша схильність до прояву такого типу булінгу по відношенню до категорії «В», як навмисне надмірне завантаження роботою у порівнянні з іншими працівниками та/або доручення завдань, які не відповідають рівню Вашої компетенції $\left(\mathrm{p}_{\leq} 0,01\right)$.

Булінг по відношенню до державних службовців категорії «В» застосовували: 59 \% - безпосередній керівник; 44,5\% - керівник вищого рівня; 29,6 \% - колеги зі структурного підрозділу; 17,3 \% керівники інших структурних підрозділів; 11,8 \% - колеги з інших структурних підрозділів; 5,5 \% - колеги з інших державних органів, 3 якими здійснюється співпраця.

За частотою булінг застосовувався: 49,3\% - систематично; $47,8 \%$ - декілька разів; 2,9\% - один раз. У 45\% колеги ставали на захист від застосування булінгу.

За захистом своїх прав державні службовці категорії «В» зверталися до таких фізичних та юридичних осіб: 61,6 \% - нікуди не звертались; 18,2 \% - безпосереднього керівника; 16,7 \% керівника вищого рівня; 14,9 \% - колег; 4,2 \% - служби управління персоналом; 0,2 \% - первинної профспілкової організації; 1,3% НАДС; 0,9 \% - суду; інших правозахисних організацій; 1,8 \% профспілки працівників державних установ України.

Також встановлено, що державні службовці категорії «В» державних органів, рівень юрисдикції яких - вся територія України, більш схильні звертатися за захистом своїх прав до служб управління персоналом, ніж державні службовці категорії «В» нижчих рівнів юрисдикції $\left(\mathrm{p}_{<} 0,01\right)$. Допомогу у вирішенні питання щодо булінгу отримали 14,9\% державних службовців. У 65,2 \% випадках булінг став причиною звільнення з посади державної служби.

За результатами кореляційного аналізу вибірки респондентів категорії «В», щодо яких застосовувався булінг, встановлено негативний кореляційний зв'язок між рівнем юрисдикції та 
продовженням/припиненням роботи на державній службі $\left(\mathrm{p}_{\leq} 0,05\right)$. Це свідчить про те, що державні службовці категорії «В», які працюють в державних органах рівень юрисдикції яких територія одного або кількох районів, міст обласного значення більше схильні до звільнення 3 посади державної служби після застосування булінгу.

Висновки. Виявлено, що 66,1 \% державних службовців стикалися по відношенню до себе з випадками булінгу на державній службі. Такі фактори, як стать, стаж державної служби та рівень юрисдикції державного органу не впливають на наявність чи відсутність факту прояву булінгу щодо державних службовців. Водночас встановлено, що існує вищий ризик застосування булінгу по відношенню до державних службовців, які займають посади державної служби категорії «В».

Близько половини державних службовців зазначили, що стикалися 3 такими проявами булінгу по відношенню до себе: постійна необгрунтована критика та незадовільна оцінка роботи керівництвом, надмірна прискіпливість та перевірка поточної роботи $(55,2 \%)$; вербальна агресія (50,9\%); поширення чуток та недостовірної інформації серед трудового колективу, що мали негативний вплив на репутацію (49,3 \%); приписування успіхів іншим працівникам, відсутність визнання досягнень і успіхів (43,5 \%); навмисне надмірне завантаження роботою у порівнянні 3 іншими працівниками та/або доручення завдань, які не відповідають рівню компетенції (38,9\%).

Також деяка частина респондентів стикалася з такими проявами булінгу, як: безпідставна зміна чи погіршення умов роботи та відпочинку (32,8 \%); навмисне обмеження доступу до необхідної інформації, право доступу до якої є (28,5 \%); умисне систематичне встановлення строку, який унеможливлює належне виконання доручення (28,4 \%); соціальна ізоляція в колективі $(20,4 \%)$; непристойні жарти, коментарі, сексуальне переслідування (16,4 \%); пошкодження документів, робочого майна тощо (3,9 \%).

За результатами кореляційного аналізу виявлено причиннонаслідкові зв'язки між деякими проявами булінгу та 
окремими статистичними характеристиками. Зокрема, такий прояв булінгу, як навмисне обмеження доступу до необхідної інформації, право доступу до якої $є$ у державного службовця, частіше застосовується щодо чоловіків та вищих категорій посад державної служби. Прояв булінгу «соціальна ізоляція» є більш характерним для державних органів рівень юрисдикції яких - вся територія України. Ризик застосування такого прояву булінгу, як навмисне надмірне завантаження роботою у порівнянні з іншими працівниками та/або доручення завдань, які не відповідають рівню компетенції, вищий щодо державних службовців з більшим стажем роботи на державній службі.

Найчастіше булінг по відношенню до державних службовців застосовували: безпосередній керівник (60\%), керівник вищого рівня $(44,4$ \%) та колеги зі структурного підрозділу $(23,4$ \%). Також частина респондентів зазначили, що булінг застосовували колеги 3 інших структурних підрозділів (17,8 \%), керівники інших структурних підрозділів $(15,7 \%)$, колеги 3 інших державних органів, 3 якими здійснюється співпраця (5,1%). Встановлено причинно-наслідкові зв'язки між проявами булінгу та особами, які його застосовують, що свідчить про схильність окремих категорій осіб до певних проявів булінгу у разі його застосування.

За результатами кореляційного аналізу також виявлено причиннонаслідкові зв'язки між категоріями осіб, які можуть застосовувати булінг та окремими статистичними характеристиками. Виявлено, що такі категорії осіб, як керівники та колеги з інших структурних підрозділів частіше застосовують булінг в державних органах з вищим рівнем юрисдикції. По відношенню до державних службовців жіночої статі булінг частіше застосовують такі категорії осіб, як керівники вищого рівня та колеги з інших структурних підрозділів. Також виявлено, що чим більший стаж державної служби, тим більший ризик застосування булінгу з боку безпосереднього керівника. За частотою по відношенню до державних службовців булінг застосовувався: 48,6 \% - систематично, 48 \% - декілька разів, 3,3 \% - один раз. Колеги ставали на захист державного службовця від булінгу у 45,1% випадків. 
За захистом своїх прав у зв'язку 3 булінгом найчастіше респонденти звертались до наступних фізичних та юридичних осіб: безпосереднього керівника $(18,8$ \%), керівника вищого рівня $(18,3 \%)$, колег $(15,1 \%)$.

Також респонденти зверталися до служби управління персоналом (3,8\%), первинної профспілкової організації (2,8 \%), НАДС (2 \%), суду (1,7 \%), інших правозахисних організацій (1 \%), профспілки працівників державних установ України $(0,6$ \%).

Водночас, більше половини респондентів, які стикалися по відношенню до себе з булінгом, нікуди не звертались за захистом своїх прав $(58,5 \%)$.

3 респондентів, що звернулися за захистом своїх прав до фізичних та юридичних осіб, допомогу у вирішенні питань щодо булінгу отримали 15,4 \% державних службовців та 84,6 \% - не отримали.

Якщо розглядати сукупність звернень до окремої фізичної чи юридичної особи, як 100 \%, то прослідковується такий відсоток, вирішених позитивно питань щодо булінгу, в результаті звернення державних службовців за захистом своїх прав до зазначених осіб: 75 \% - профспілки працівників державних установ України; 35,5 \% служби управління персоналом; 35,3 \% - Первинна профспілкова організація; 34,7 \% - колеги; 29,7 \% - керівник вищого рівня; $28,7 \%$ - безпосередній керівник; $16,7 \%$ - суд; 14,3 \% - НАДС; 11,1 \% - інші правозахисні організації.

Встановлено, що державні службовці, які працюють у державних органах з рівнем юрисдикції - вся територія України частіше звертаються за захистом своїх прав у разі застосування булінгу до суду та Первинної профспілкової організації, ніж державні службовці, які працюють в державних органах інших рівнів юрисдикції.

Серед державних службовців, які звільнилися з посади державної служби, булінг став причиною звільнення у 64,9 \% випадках.

Статистично встановлено, що чим більше державні службовці стикаються з булінгом, тим більша імовірність, що вони припинять проходження державної служби. Зокрема, такі прояви булінгу, як вербальна агресія, пошкодження документів, робочого майна у 95- 
99 \% випадків їх застосування провокують державних службовців до звільнення.

Також імовірність звільнення державного службовця після застосування булінгу підвищується, якщо булінг застосовують колеги зі структурного підрозділу та безпосередній керівник.

Порівняння застосування булінгу по відношенню до державних службовців, які займають різні категорії посад державної служби свідчить, що серед опитуваних стикалися із застосуванням булінгу: 50 \% - державних службовців, які займають посади категорії «А»; 60,4 \% - державних службовців, які займають посади категорії «Б»; 69,9 \% - державних службовців, які займають посади категорії «В».

Визначено найбільш поширені прояви булінгу: щодо категорії «А»: вербальна агресія (71,4%), постійна необгрунтована критика та незадовільна оцінка роботи керівництвом, надмірна прискіпливість та перевірка поточної роботи (57,1%), поширення чуток та недостовірної інформації серед трудового колективу, що мали негативний вплив на репутацію (57,1 \%), непристойні жарти, коментарі, сексуальне переслідування (57,1 \%); щодо категорії «Б»: постійна необгрунтована критика та незадовільна оцінка роботи керівництвом, надмірна прискіпливість та перевірка поточної роботи $(58,5 \%)$, поширення чуток та недостовірної інформації серед трудового колективу, що мали негативний вплив на репутацію (54\%), вербальна агресія (49,1 \%), приписування успіхів іншим працівникам, відсутність визнання досягнень і успіхів (47,8 \%); щодо категорії «В»: постійна необгрунтована критика та незадовільна оцінка роботи керівництвом, надмірна прискіпливість та перевірка поточної роботи (55 \%), вербальна агресія (51,5\%), поширення чуток та недостовірної інформації серед трудового колективу, що мали негативний вплив на репутацію (46,7 \%).

Отримані результати опитування щодо булінгу на державній службі будуть враховані в ході розробки Генеральним департаментом 3 питань управління персоналом на державній службі НАДС Концепції культури на державній службі.

\section{Стаття надійшла до редакції: 12.04.21}




\section{BULLYING IN THE PUBLIC SERVICE: SOCIO-PSYCHOLOGICAL ASPECTS}

Nataliia Aliushyna, $\mathrm{PhD}$ in Psychology, Head of the National Agency of Ukraine on Civil Service, Kiev, Ukraine.

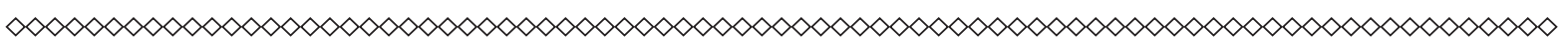

The scientific article presents the results of a socio-psychological research on the manifestations of bullying in the public service in Ukraine. It was revealed, using the method of a sociological survey, cases of the use of bullying, the features of the manifestation of this phenomenon and the ways of protecting the rights of civil servants in connection with bullying were investigated. 1,042 civil servants took part in the survey. The survey was carried out using a questionnaire method. When processing the survey results, the method of correlation analysis (Pearson's correlation coefficient) was used. Determination of correlations was carried out using the IBM SPSS Statistic 21 software.

Key words: civil service, civil servants, personnel management, socio-psychological mechanism of personnel management, bullying, harassment.

\section{Received: 12.04.21}

\section{References}

1. Bogomolov, V.A. (2013). Orientirovannyiy na reshenie podhod v rabote $s$ situatsiyami travli $v$ shkole [Solution-oriented approach to dealing with bullying situations in school]. Retrieved from http://www.sfbt.ru/2013/02/ blog-post_5804.html [in Russian].

2. Bochaver, A.A., \& Hlomov, K.D. (2014). Kiberbulling: travlya v prostranstve sovremennyih tehnologiy [Cyberbullying: bullying in the space of modern technologies]. Psihologiya: Zhurnal Vyisshey Shkolyi Ekonomiki Psychology: Journal of the Higher School of Economics, (Vols. 11), 3, (pp. 178-191) [in Russian]. 
3. Guseynova, E.A., \& Enikolopov, S.N. (2014). Vliyanie pozitsii podrostka $\mathrm{v}$ bullinge na ego agressivnoe povedenie i samootsenku [The influence of a teenager's position in bullying on his aggressive behavior and self-esteem]. Psihologicheskaya nauka i obrazovanie - Psychological science and education, (Vols. 6), 2, (pp. 246-256). Retrieved from http://psyedu.ru/journal/2014/2/ Guseinova_Enikolopov.phtml [in Russian].

4. Kon I.S. Shkolnoe nasilie: bulling $i$ heyzing [School Violence: Bullying and Hazing]. Retrieved from http://rumagic.com/ru_zar/sci_psychology/kon/1/ j62.html [in Russian].

5. Young, S. (1998). The support group approach to bullying in schools. Educational Psychology in Practice, 14, 1, (pp.32-39) [in English].

6. Salisbury, J. (1999). Challenging Macho Values: Ways of Working with Boys in Secondary Schools. Retrieved from http:/site.ebrary.com/lib/bckharkiv/ Doc?id=100957668 [in English].

7. Dankanson, N. (1999). Sexual Bullying: Gender Conflict and Pupil Culture in Secondary Schools. Retrieved from http:/site.ebrary.com/lib/ bckharkiv/Doc?id=10071157 [in English].

8. Kon, I.S. (2006). Chto takoe bulling i kak s nim borotsya? [What is bullying and how to deal with it?]. Semya i shkola - Family and school, 11, (pp. 15-17) [in Russian].

9. Randall, P. (2001). Bullying in Adulthood: Assessing the Bullies and Their Victims. USA: Brunner-Routledge. Retrieved from http:/site.ebrary.com/ lib/bckharkiv/Doc?id=10053591 [in English].

10. Berger, K. (2014). Invitation to the Life Span. New York: Worth Publishers. Retrieved from http://lp.booNbane.com/invitation-to-the-life-spantext-only-1st-first-edition-by-N-s-berger.pdf?refhost=ideapod. [in English].

11. Main definitions of bully in English. (n.d.). en.oxforddictionaries. com. Retrieved from https://en.oxforddictionaries.com/definition/bully [in English].

12. Miskevich T.(2019). Rehuliuvannia problemy bulinhu na zakonodavchomu rivni: pershi kroky Ukrainy ta svitovyi dosvid [Regulating the problem of bullying at the legislative level: the first steps of Ukraine and world experience] Hromadska dumka pro pravotvorennia - Public opinion on lawmaking, № 1 (166). - C. 18-22. - Retrieved from http://nbuviap.gov.ua/ images/dumka/2019/1.pdf. [in Ukrainian]. 


\section{Відомості про авторів / Information about the Authors}

Алюшина Наталія Олександрівна: Національне агентство України з питань державної служби: вул. Прорізна, 15, м. Київ, 01601, Україна.

Nataliia Aliushyna: National Agency of Ukraine on Civil Service: 15 Prorizna str., Kiev, 01601, Ukraine.

ORCID. ORG./ 0000-0003-1333-3800

E-mail: natalyushina@gmail.com 